\title{
Corporate social responsibility and international business: examining the nexus and gaps from a developing economy perspective
}

\author{
Robert Ebo Hinson ${ }^{1}$, Frederick Avornyo ${ }^{1 *}$, John Kuada ${ }^{2}$ and Felix Ankomah Asante ${ }^{3}$
}

\begin{abstract}
Research into Corporate Social Responsibility (CSR) in Ghana generally, has seen increased scholarly attention but same cannot be said of the specific area of CSR and International Business (IB), ironically though much of the data on CSR research comes from IBs. This paper therefore reviews existing literature on CSR in Ghana with the objective of identifying gaps and developing a framework to guide future research in CSR and IB because of the peculiarities. The paper underscores the varying and conflicting interests of host and home nations as well as international standards that IBs must navigate in their CSR activities, and applies Impression Management theory to develop a framework for future studies in the subject area in Africa and emerging economies.
\end{abstract}

Keywords: CSR, International Business, Impression Management

\section{Introduction}

Ghana is considered a beacon of democracy in SubSaharan Africa, with seven (7) successive successful elections including changes in governments which is a rare phenomenon in the region. This, in addition to her wealth in natural resources make her one of the leading countries in Africa (Ghana Investment Promotion Centre website). The country has enjoyed an accelerated economic growth over the past decade with the resultant attainment of the Millennium Development Goal (MDG) of halving poverty (Poverty Reduction in Ghana: Progress and Challenges by the World Bank) and was ranked as the "Best Place for Doing Business in the ECOWAS Region"(World Bank Doing Business Report 2014). These feats, in addition to technological advancement (130.97\% mobile penetration and $68.18 \%$ for mobile data penetration according to the National Communications Authority Industry Information report for March 2016), has made her one of the attractive destinations for foreign capital, resulting in a significant number of multinational companies operating in the country, with their peculiar intricacies. Ghana, just

\footnotetext{
* Correspondence: efoh@hotmail.com

'University of Ghana Business School, P.O. Box LG 78, Legon-Accra, Ghana Full list of author information is available at the end of the article
}

as other African countries and indeed emerging economies, is currently reeling under global drop in commodity prices with the attendant foreign exchange volatility and widened trade, and budget deficit with far reaching consequences on businesses. It is our contention that these qualifiers make a Ghana based study on corporate social responsibility and international business important contribution to existing literature.

Corporate Social Responsibility (CSR) has gained prominence in scholarship in Sub-Saharan Africa (Tilt, 2016) with many looking at various aspects of it. The CSR literature on Ghana and other African countries used to be scanty and could still be argued to be less exhaustive in comparison to a developed country's CSR research; but there has been sufficient academic interest in the subject in recent times prompting Tuokuu and AmponsahTawiah (2016) to suggest that the concept was no longer nascent in the West African country. A review of the extant literature on CSR in Ghana shows that research into the concept picked up from the $21^{\text {st }}$ century, although there is evidence of CSR in Ghana as far back as 1939 (Ofori 2010a, 2010b). Most of the studies undertaken in CSR in Ghana have focused on organisational practices and management perspectives; 
stakeholder perspectives; communication of CSR activities; CSR and firm performance; as well as firm characteristics and CSR. Although most of these studies derive their empirical data from multinationals because they play a lead role in CSR programmes (AmponsahTawiah, \& Dartey-Baah, 2011), it appears no deliberate effort has been made to critically focus on the concept of CSR within the context of IBs. Of particular importance are moderating factors that could impact CSR activities of international firms in host countries.

Scholars who made a foray into CSR and IBs in Ghana were largely within the arena of comparative analysis of the characteristics of multinationals vis-a-vis their indigenous counterparts in relation to their orientation towards the concept (Hinson and Ofori 2007: Kuada \& Hinson, 2012). Others such as Dartey-Baah and Amponsah- Tawiah (2011) examined the applicability of Western CSR theories to Africa and for that matter Ghana but none of the literature reviewed, has holistically considered CSR within the context of IB in Ghana. However CSR and IB has gained sufficient attention in developed countries, (Kolk, 2016: Gruber, \& Schlegelmilch, 2015).

The conceptualisation of CSR, remains a grey area characterised by disputes over an agreed definition (Nyuur et al., 2014). One of the early scholars Carroll (1991) characterised CSR into four responsibilities in a pyramidal form to depict the order of importance and their historical development but argues that all four co-exist; Philanthropic Responsibilities, Ethical Responsibilities, Legal Responsibilities and Economic Responsibilities. Subsequent to this study, characterisation of CSR by other scholars appears to revolve around the work of Carroll (1991). However, Visser, (2006) critiqued Carroll's conceptualisation of CSR arguing that it was North America biased and not entirely applicable to the African context. Using Carroll's classification, he argues that unlike Carroll who makes philanthropic responsibility the last in the hierarchy of responsibilities, within the African context, Philanthropic responsibility is the second most important, because of issues of poverty and underdevelopment. Visser's (2006) argument is not unfounded as CSR motives in North America is even considered distinct from Europe (Capaldi, 2016).

It can be inferred from Visser (2006) that what influences CSR in the West may differ from Africa and developing countries, a view shared by Kuada and Hinson (2012), who further argue that firms CSR activities are influenced by the cultural values of host nations. They have also argued that multinationals are mindful of international standards and CSR certification agencies while Gruber \& Schlegelmilch (2015) have also thrown up the issue of "global consistency and local responsiveness" as potential challenges that confronts IBs in their CSR activities. These observations suggest that international firms are presented with a unique challenge that can impact how they undertake their CSR activities and we argue that a study of CSR and IB should be situated within this context. Although scholars like Marano \& Kostova (2016) admit to this peculiarity, they however limit the elements to host country and parent company influence only, excluding international Non-Governmental Organisations (NGOs), rating agencies and home country influence, which are additions that this study proposes should also be considered.

Predominantly, Stakeholder and Institutionalisation theories have been used in CSR studies in Ghana (Tuokuu \& Amponsah-Tawiah, 2016; Dartey-Baah, et al., 2015; Hinson \& Kodua, 2012), however beyond the interest of stakeholders, firms, in carrying out CSR are also mindful of their reputation and public impression (Gruber \& Schlegelmilch 2015; Ofori 2007a, 2007b). The paper therefore proposes that CSR and IB research can be anchored on the Impression Management (IM) Theory.

The objective of this paper therefore is to position CSR and IB research within the context that we argue is more representative of the reality. This stance is influenced by a thorough review of literature on CSR in Ghana; sifting out the dominant themes, arguments, theories and methodologies, which are evidently captured in a tabular form. We identify gaps that back our stance and suggest a framework to guide research into CSR and IB in emerging economies such as Ghana. The paper is structured as follows; firstly, the investigative methodology and search protocol used; a description of the included literature in terms of year of publication, research methods applied and level of analysis. We also present an assessment of theories on which the studies were anchored. We then assess the conversation on IB and CSR in Ghana and finally we propose a theoretical framework to guide future research.

\section{Investigation method}

Literature on CSR and IB in Ghana is very scanty, however snippets of issues bordering on IB and CSR are mentioned in several studies done on CSR in Ghana. Sticking strictly to literature on CSR and IB in Ghana may therefore not be comprehensive. This paper, as a result looks broadly at CSR within the context of Ghana. It has been argued that a review could be subjective if it is done without rigour and could affect the reliability of knowledge. However if it is carried out systematically, it could provide the most efficient and reliable knowledge with a wide reaching coverage for scholarly works (Cooper, 2010; Denyer, \& Tranfield, 2006; Cook, 1997). The researchers therefore attempted to inculcate the merits of systematic review in this work, which according to Kera"nen et al. (2012) are "its methodological rigour, transparency, pragmatism, exhaustive literature coverage and reproducibility". 


\section{Scope of research}

The research covered 75 journal articles from different databases. It was subsequently pruned to 27 , based on the relevance of the research and the quality of journal in which the articles are published. The expansive nature of CSR required that reviewed articles be limited to thematic areas directly related to business organisations and also limited to published academic journals because they have already gone through rigorous peer review which is an indication of a suitable quality.

\section{Search strategy}

A search was conducted for published journal articles using the search words; Corporate Social Responsibility, Corporate Responsibility, Sustainability, International Business and Ghana from key databases. The databases include Taylor \& Francis, Emerald, Elsevier, Sage, ProQuest and Google Scholar. The searches were conducted within the search windows provided on the website of the databases and therefore did not require stating the document type (Kera"nen et al. 2012). The initial search was limited to the titles of the publications. The abstract and keywords of the initially selected articles were then reviewed to come up with the preferred publications. To establish the suitability of some of the articles, a cursory review of their introduction was also carried out. To ensure that the publications are of acceptable quality, publications found in lesser known journals based on their low impact factor (Franke, et al., 1990) were excluded, after which full texts were obtained by downloading soft copies. Much as journal impact factor is not an absolute measure of the quality of an academic paper, an article with a high impact factor suggests that it has been cited by many researchers, who themselves are prime consumers of the articles (Saha et al., 2003). Rosenstreitch \& Wooliscroft, (Rosenstreich and Wooliscroft 2012) critiqued the use of journal impact factor for marketing related researches but their aversion was in relation to "the time lag before citation of marketing articles" and not the relevance of journal impact factor ranking. Faced with the constraints of time and resources, we are of the view that articles from high impact factor journals would be representative of the general academic discourse on CSR in Ghana. Additionally, the use of high impact factor journal solves a criterion challenge as to which articles to include and which to exclude in a more systematic manner. We are also of the opinion that the arguments that might be presented by low impact factor journals, are not likely to be missed, if the review is based largely on high impact factor journals which invariably are the most cited articles.

Conference papers published in journals were eliminated from the list while publications which are in themselves literature reviews were not included.

\section{Description of literature}

The final 27 identified peer-reviewed journal articles have been variously cited in other publications. This is to ensure that the included literature is of appreciable level of acceptability by other scholars.

\section{Publication activities}

Although there is evidence of CSR taking place in Ghana as far back as 1939 (Ofori 2010a, 2010b), scholarship in the area is a recent phenomenon (Ofori 2007a, 2007b; Abugre 2014). It is therefore not surprising that much of the included literature is post 2010. Indeed, none of the selected scholarly work included in this review was published before 2006 as shown in Fig. 1.

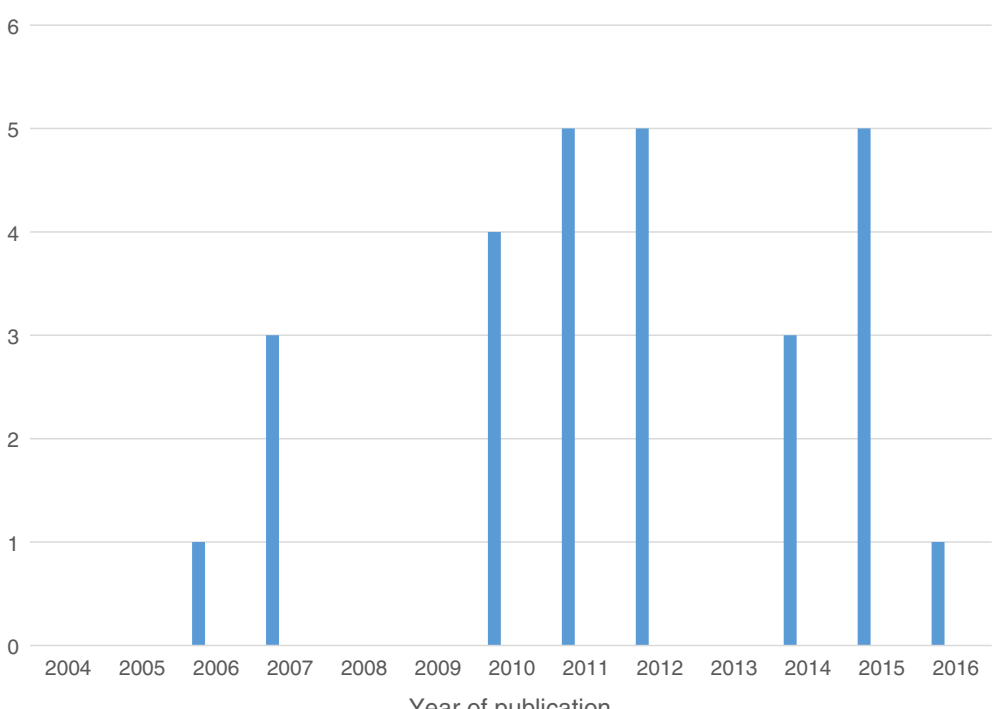

Fig. 1 Year distribution of included articles on CSR in Ghana 
Out of the 27 selected articles, 23 of them representing almost 85.1\% were published between 2010 and 2016 . The increased research into the subject matter could also be due to increased publication of CSR activity by organisations (Hinson, 2011; Abugre, \& Nyuur, 2015.) as well as heightened activity by civil society actors (Amponsah-Tawiah, \& Dartey-Baah, 2011).

A review of the included literature also showed that only five (5) articles representing $18.5 \%$ directly discussed CSR within the context of IB. Broadly, six major themes were identified from the included literature. They include Scope of CSR; Organisational Leadership and Management Perspective of CSR; CSR and Stakeholders Perspective; CSR and Firm Performance; CSR \& Firm size/type and CSR Communications. Some articles have more than one of the identified themes running through. Of the six thematic areas identified, close to $52 \%(51.85 \%)$ of the articles either examined broadly the scope of CSR or considered the management perspective of it or both. The other thematic areas identified such as the link between the firm type or size and their CSR activities, CSR and firm performance, and the communication of CSR activities also made modest showing. A diagrammatical representation of the thematic areas is presented in Fig. 2 below.

From the chart, it can be gleaned that research that focuses on the scope of CSR (General Scope) as well as organisational leadership and management (Mgt \& CSR) and stakeholder perspective (CSR \& Stakeholders) are the three dominant themes, while CSR and firm performance had the least. Figure 3 demonstrates the wide

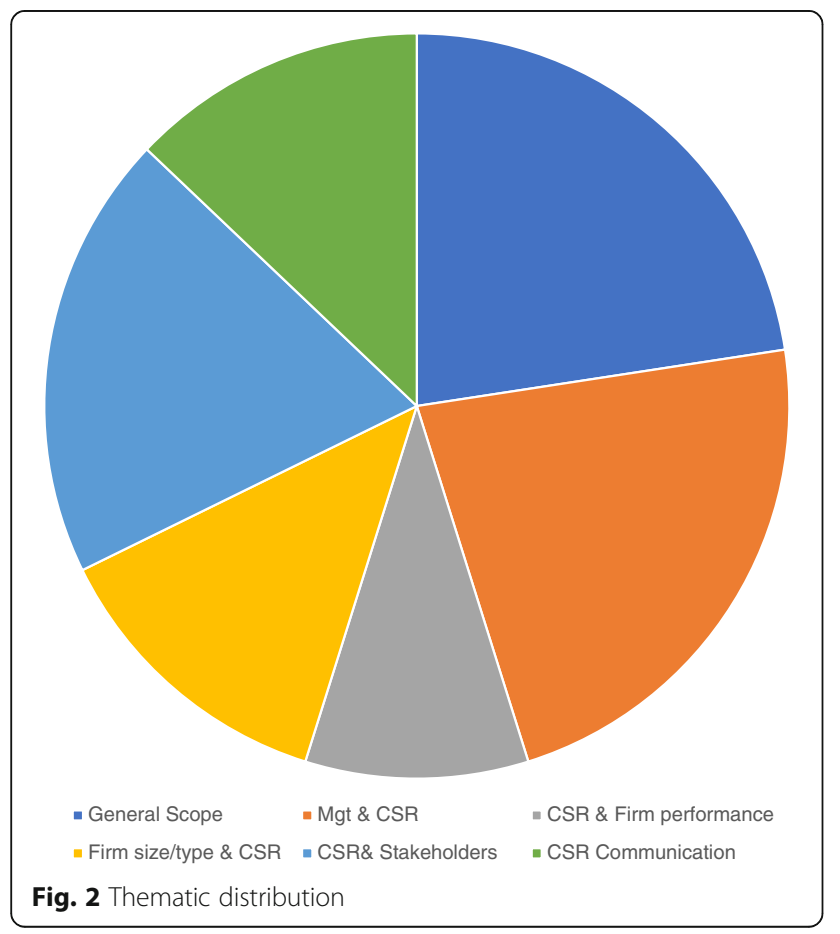

disparity between the number of articles reviewed for the purpose of this paper and the percentage that focused somewhat on IB.

In terms of methodology, majority of research in the area are empirical $(81.48 \%)$ with more of the papers applying qualitative methodology (70.38\%) and less of quantitative approaches to the studies.. To facilitate this literature review, the selected articles have been assigned numbers from one (1) to twenty-seven (27) in no particular order and grouped under the identified thematic areas as shown in Table 1 below.

Table 1, provides a snap shot of the distribution of research methodology with the dark shaded areas indicating the gaps. For instance, it shows that under the thematic area Scope of CSR, five articles numbered 11, $12,13,17$ and 19 are empirical while only two articles numbered 9 and 25 are conceptual. It can be further seen that of the empirical papers under the theme Scope of CSR, four $(11,12,17,19)$ applied qualitative methodology with only one (13) applying mixed methods. It indicates how mixed methods are sparingly used accounting for only $3.7 \%$ of included literature. This suggests that more researches could be done using mixed methods to afford scientists the benefit of applying the rigour that comes with quantitative methods and the additional insight that the explorative nature of qualitative research provides (Denscombe, 2008). At the level of analysis, there was a preponderance of multi-firm level analysis (88.88\%) with only 3 articles representing $11.1 \%$ of the peer reviewed journal articles undertaking firm level analysis (Table 2).

\section{Theoretical assessment}

It is observed that not all articles have theoretical underpinnings while stakeholder and institutionalist theories appear to be dominant where theories are applied. The dominance of Stakeholder theory could be premised on the argument that corporate entities exist to satisfy other agents connected to them besides shareholders (Branco \& Rodriques 2007). Considering the fact that the Stakeholder theory posits that firms must seek the interest of all stakeholders (Dartey-Baah et al., 2015), it stands to reason that it will be the obvious choice of many scholars.

Dartey-Baah, et al. (2015) who looked at CSR in Ghana's development argue that since the country is a stakeholder to an organisation, the organisation should ensure that its activities incorporates the interest of the country. They use this explanation as basis for adopting the Stakeholder theory. Hinson and Kondua (2013) also argued that theorists will be better served if discussions on CSR and Marketing are based on "stakeholder orientation rather than a narrow market orientation". They adopt Maignan et al. (2005) stakeholder model in their study and suggest that firms must determine the 


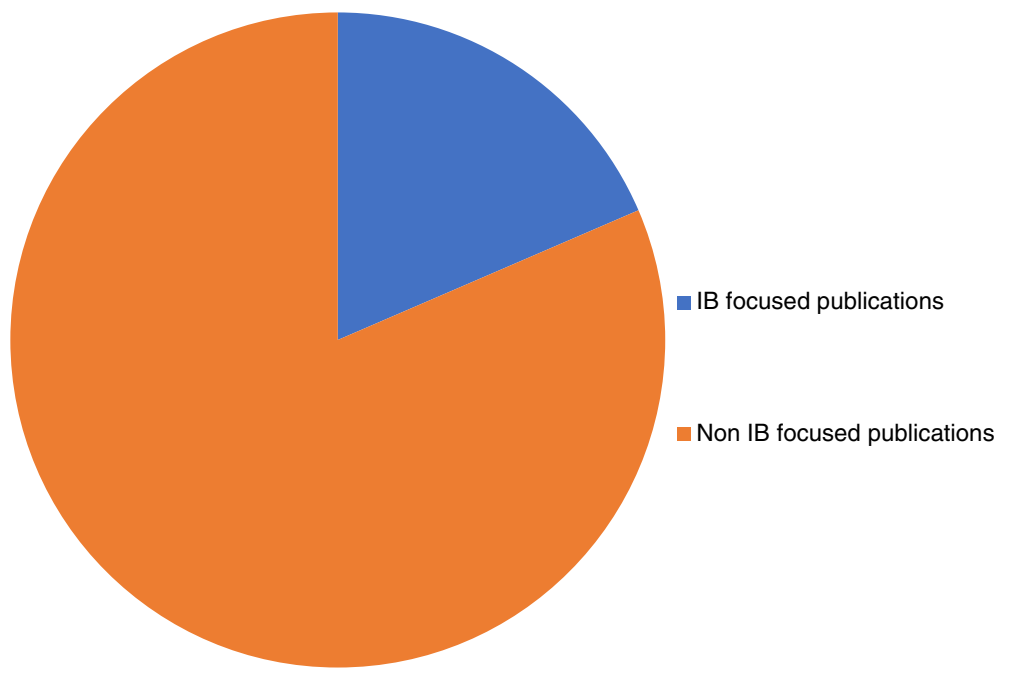

Fig. 3 Focus of publications

interests of their stakeholders in rolling out their CSR programmes. Tuokuu and Amponsah-Tawiah (2016) are more emphatic, arguing that "CSR takes its roots from the stakeholder theory". They further subdivide stakeholders into internal and external and posit that "CSR programmes cannot be executed" if organisations fail to receive stakeholders' cooperation, a view held by other scholars (Huang \& Zhao, 2016). Hinson et al. (2015) who share similar disposition expand the argument further by suggesting that organisations are pressured to report on their sustainability activities due to institutional and stakeholder influence. They therefore adopt both institutional and stakeholder theory in their study. Dashwood and Puplampu, (Dashwood and Puplampu 2010) also anchored their study on rational choice institutionalism and historical institutionalism. They argue that the theories allow them to consider how institutional norms influence firm behaviour around CSR.

Despite the preponderance of the Stakeholder theory, other theories such as leadership theories (Dashwood \&
Puplampu, 2010; Ofori 2010a, 2010b) and neo classical theories (Hinson \& Ndhlovu) have also underpinned some of the CSR in Ghana studies. Scholars who adopted leadership theories looked at how organisational leadership impacted outcomes of CSR activities while those who adopted neo classical theory juxtaposed it with the Keynesian theory, explaining that while the neo classical theorists saw CSR as a deflection from the core objective of a firm, the Keynesian theorists hold a contrary view.

Evidently, out of 27 CSR in Ghana articles reviewed, only 9 had a theoretical underpinning, representing 33\%. This is in sharp contrast to what pertains in CSR scholarship globally. In a review of CSR and international marketing, only a third of articles reviewed was not anchored on a theory (Eteokleous, et al., 2016). However just as Eteokleous et al. (2016) found out, Stakeholder theory was the dominant theory applied. In their review, $21.7 \%$ of the articles used the Stakeholder theory but as much as $55.5 \%$ applied it in the case of CSR in Ghana. Institutional and leadership

Table 1 Methodological distribution

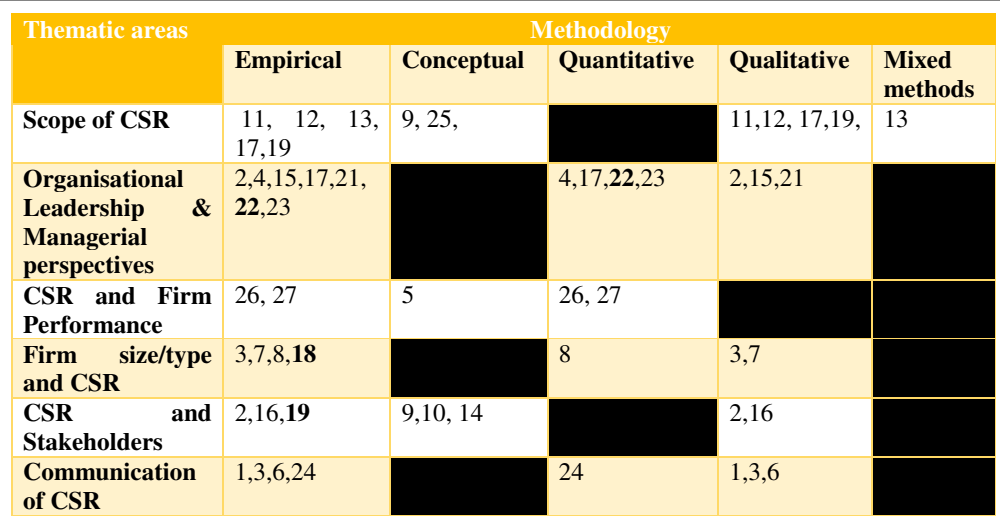




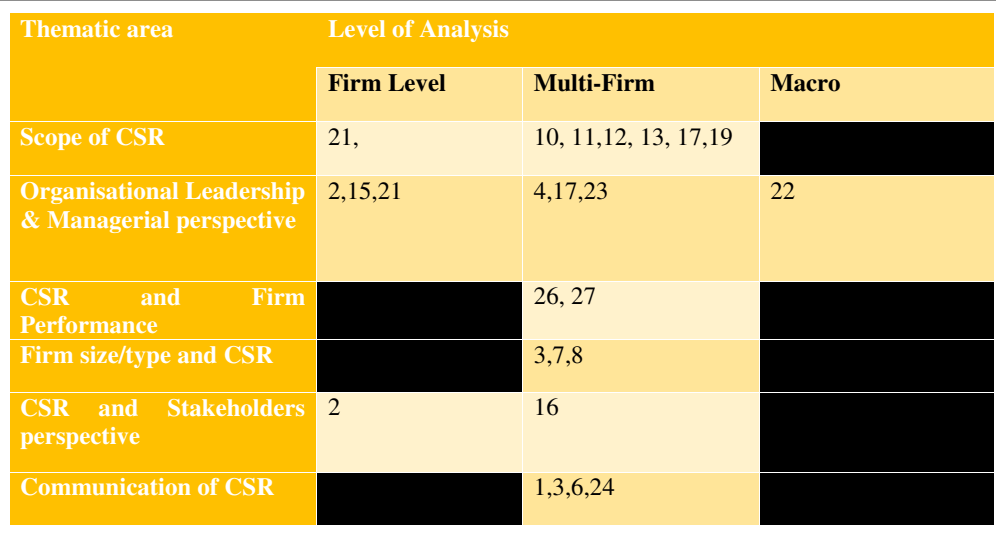

The preponderance of multi-firm or multiindustry studies could also be because it is considered to have a higher level of generalisability of research result (Keränen et al. 2012). The dark shaded boxes are indicators of the identified gaps

theories were the second most applied theories based on the included literature on CSR in Ghana. Although several scholarly works considered the public relations role of CSR (Hinson \& Ofori 2007), it appears researchers have not considered looking at theories such as Impression Management that seeks to explain the image or reputation aspect of CSR activities.

\section{The empirical evidence of CSR studies in Ghana}

CSR has witnessed increased interest in both academics and practice in Ghana and many researches bear testimony to that fact. The various studies have varied objectives as well as findings. Table 3 is a taxonomy of the included literature.

\section{Assessment of CSR in Ghana and IB}

The genesis of IB has been traced to the launch of the Journal of World Business in 1965 and given additional impetus with the launch of the Journal of International Business Studies in 1970 (Kolk, 2016). It can be generally defined as a firm level business that is conducted "in a location other than the firm's home country" and involves "interrelationships between the operations" of the firm and the foreign environment in which it operates (Kolk, 2016). Ghana has attracted a lot of international businesses over the years investing in various sectors of the economy (Ghana Investment Promotion Centre website). A review of the extant literature on CSR in Ghana however suggest that only few studies contextualised the research within the domain of IB although as earlier stated, much of the empirical data on CSR are from multinationals. While some studies made significant inroads into the area of $\mathrm{IB}$, a lot more just made references to it in passing. Kuada and Hinson, (Kuada and Hinson 2012) specifically set out to do a comparative study on CSR practices between local and foreign firms and opined that while CSR programmes of multinationals are largely "guided by legal prescriptions" that of their indigenous counterparts are "guided mostly by discretionary and social considerations". The scholars also share in the argument that generally, the cultural values of a community impact the operations of firms and suggest further that companies with foreign connections are conscious of their international image and additionally, that they take instructions from their headquarters. These assertions could have been stretched further to determine how the factors of societal values, instructions from headquarters and international standards jointly could mediate or impact the CSR orientation and implementation of multinational firms. For instance, giving gifts to traditional rulers is a standard practice in Ghana but that could easily be misconstrued as bribe at the international stage and firms could be caught in such a web. These potential sources of conflict, fueled by opposing values and standards are worth investigating.

Studies have postulated that while philanthropic responsibility is highly rated in Ghana and developing economies in general, ethical issues are highly rated in advanced countries (Kuada \& Hinson 2012, Hinson \& Ofori 2007). So, while a multinational company may desire to be more ethical and score high on international CSR ratings, that may not be the priority of the community within which they operate. Visser, (2006), Amponsah-Tawiah and Mensah, (2015) have all argued that ethical issues such as workplace health and safety is rated low in developing countries and it would be interesting to know how foreign firms navigate these slippery grounds and whether they are sometimes compelled to sacrifice one for the other and possibly which one is mostly sacrificed; the local or international considerations.

Dashwood and Puplampu, (2010) on their part, observe how pressure from both civil society and government of Canada influenced the operations of mining companies in host nations. This home-based pressure, 


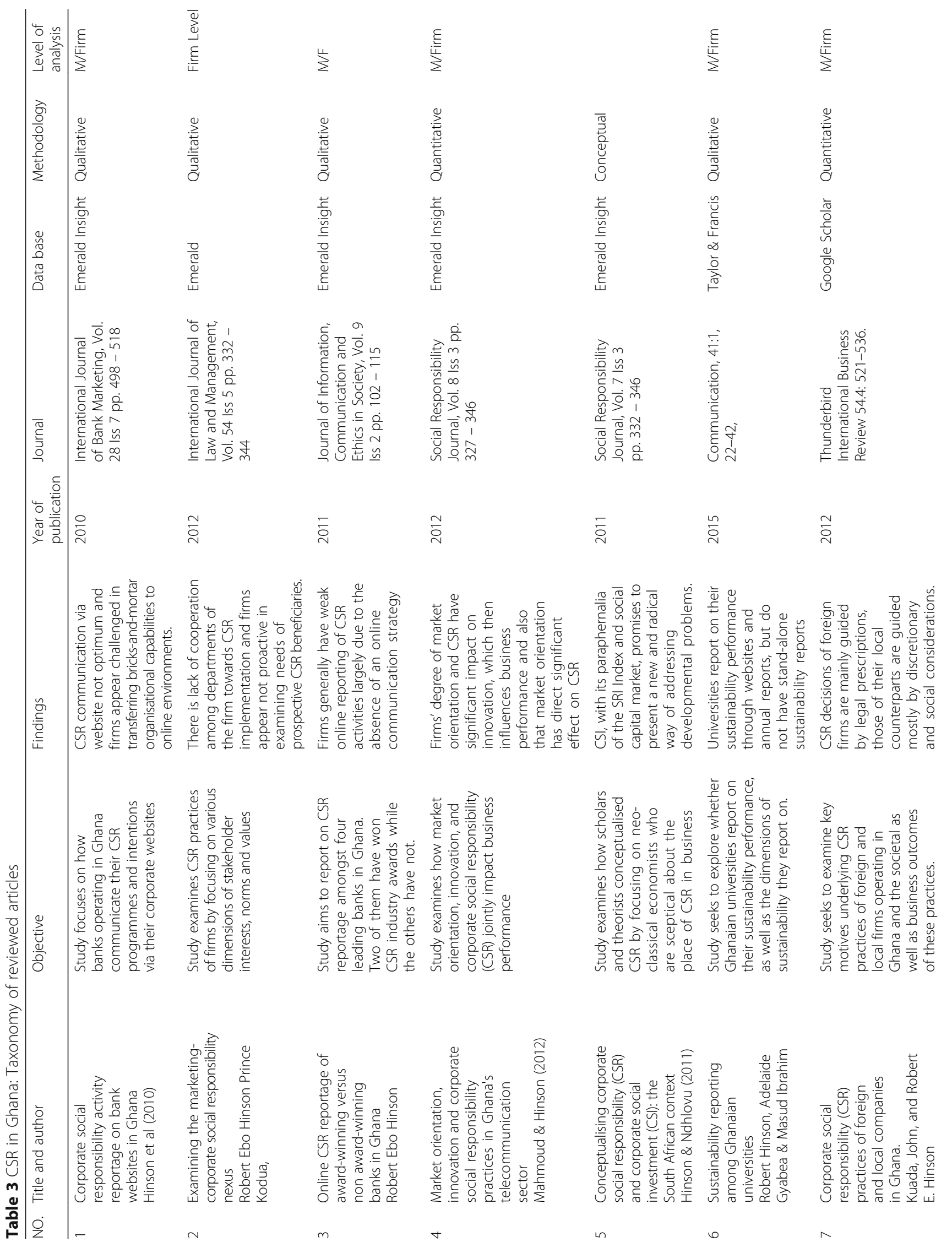


$\stackrel{\xi}{\sum}$

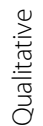

$\frac{\overline{0}}{\frac{0}{0}}$

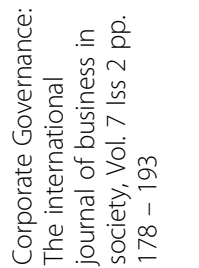

ఫे

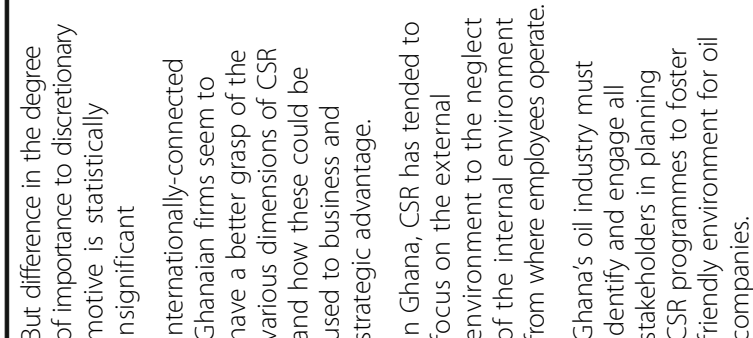

$\stackrel{\xi}{\sum}$

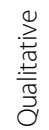

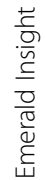

$\stackrel{\xi}{\sum}$

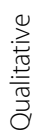

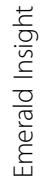

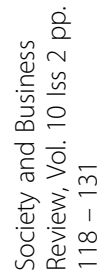

$\stackrel{n}{\grave{2}}$

ลั

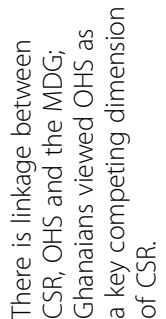

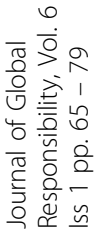

$\stackrel{\llcorner}{\stackrel{2}{\circ}}$

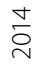

$\stackrel{\infty}{\stackrel{\sim}{*}}$

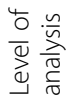

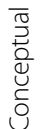

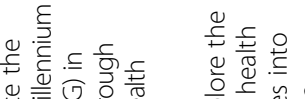

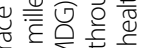

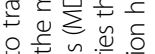

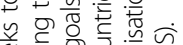

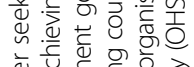

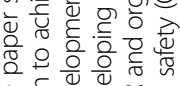

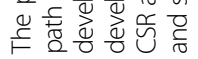

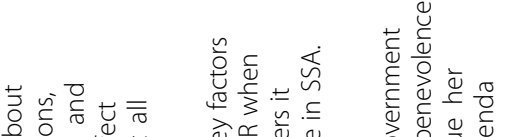

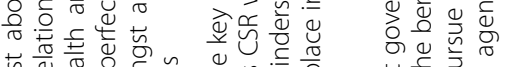

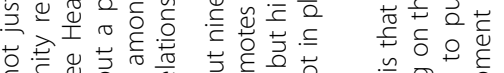

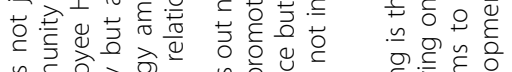

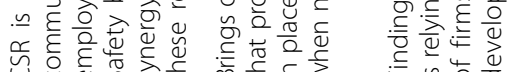

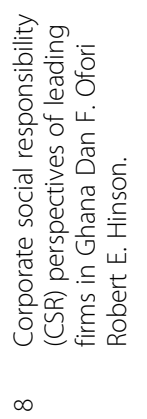

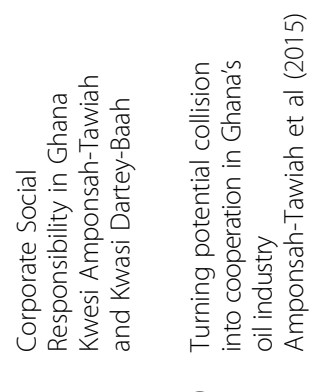

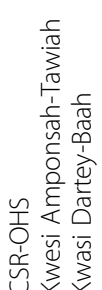

岳产离

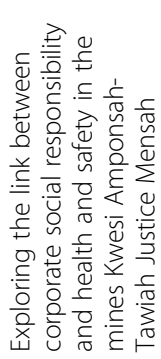

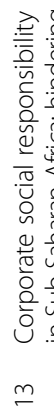

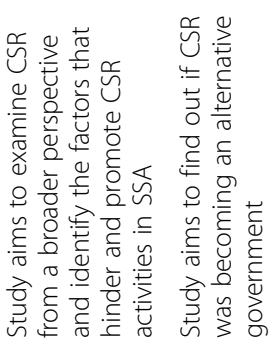

$\simeq$

बे

웡응

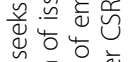

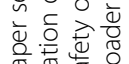

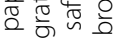

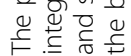

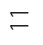

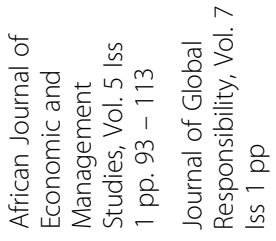




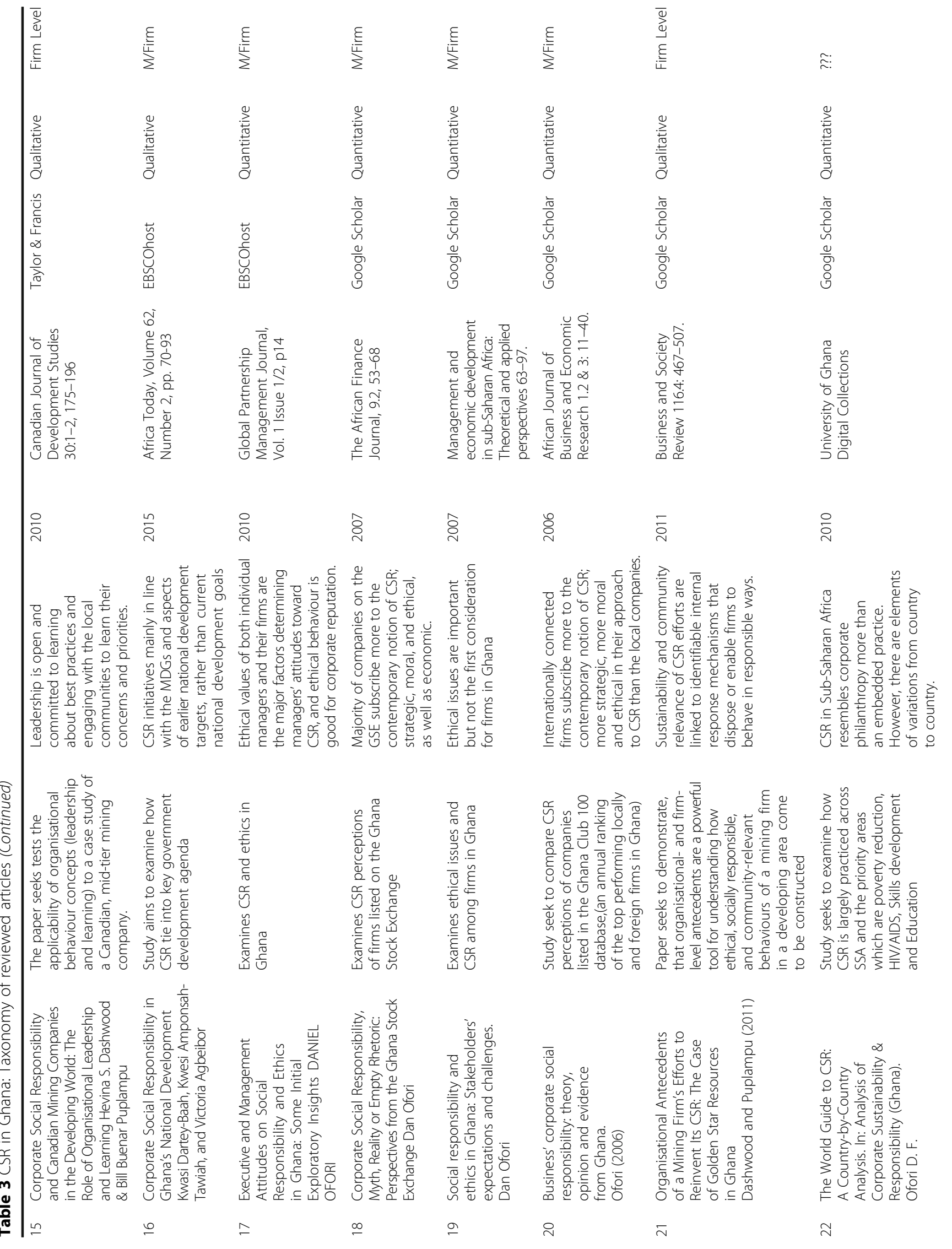




\begin{tabular}{|c|c|c|c|c|}
\hline$\frac{\xi}{\sum \frac{\xi}{k}}$ & $\stackrel{\xi}{\underline{\xi}}$ & $\approx$ & $\underset{\sum}{\underline{\underline{\xi}}}$ & ‡: \\
\hline 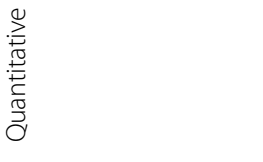 & 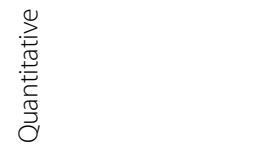 & 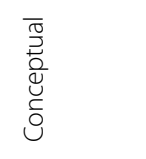 & 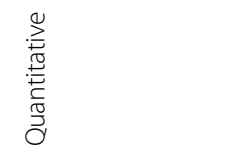 & 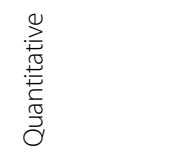 \\
\hline 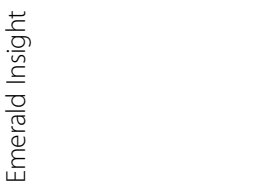 & 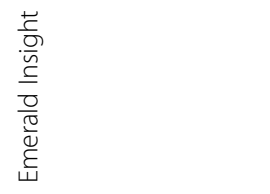 & 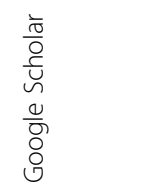 & 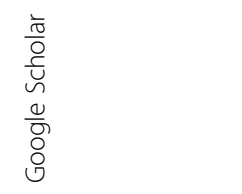 & $\begin{array}{l}\frac{\bar{\sigma}}{0} \\
\overline{\mathrm{V}} \\
\mathrm{u} \\
\frac{\omega}{8} \\
8 \\
\end{array}$ \\
\hline 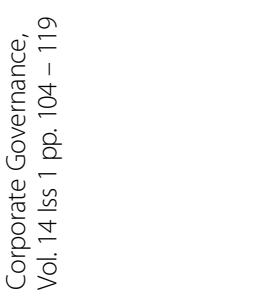 & 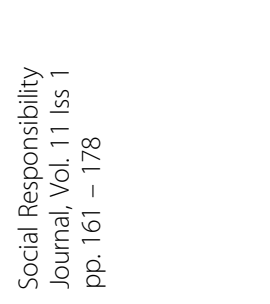 & 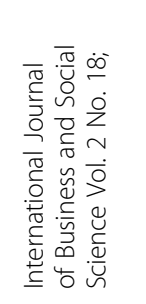 & 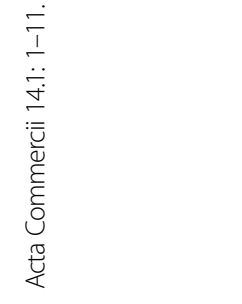 & 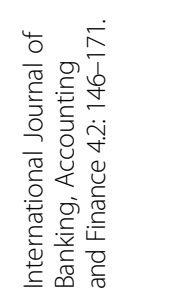 \\
\hline$\stackrel{g}{t}$ & $\stackrel{n}{\stackrel{n}{n}}$ & $\overline{\bar{\sigma}}$ & $\stackrel{+}{\stackrel{D}{d}}$ & $\tilde{\check{d}}$ \\
\hline 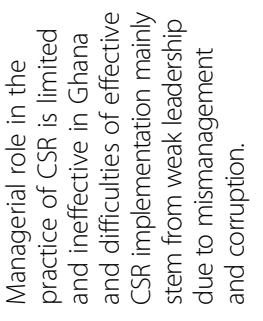 & 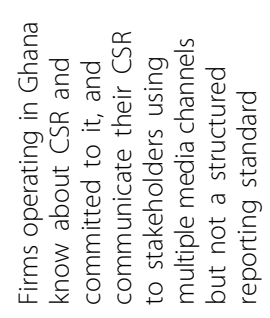 & 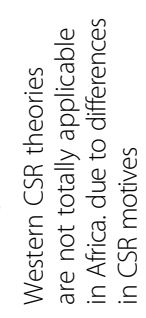 & 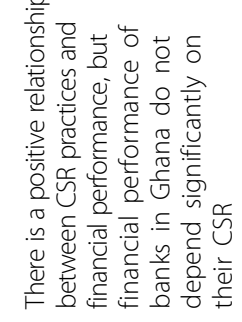 & 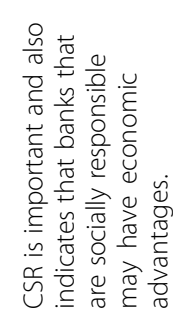 \\
\hline 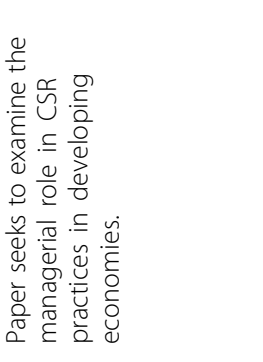 & 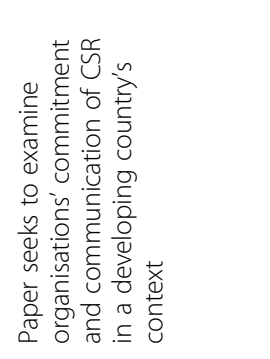 & 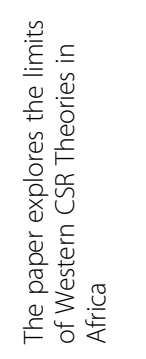 & 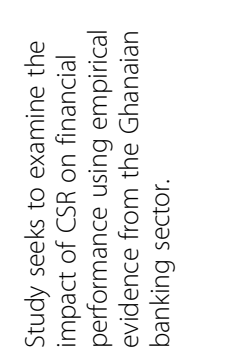 & 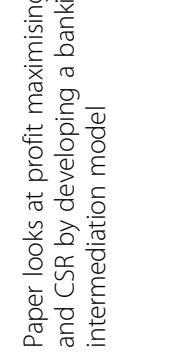 \\
\hline 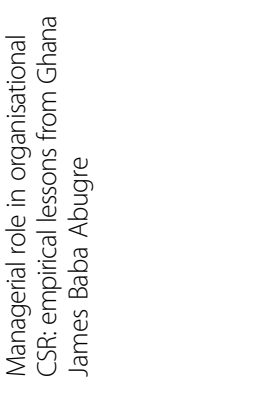 & 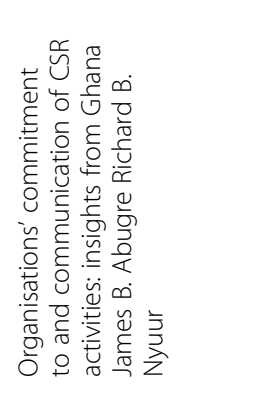 & 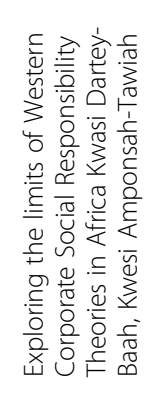 & 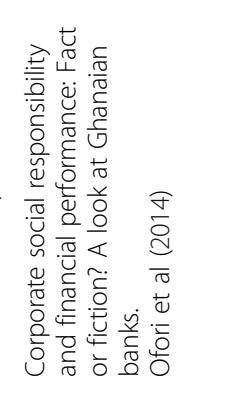 & 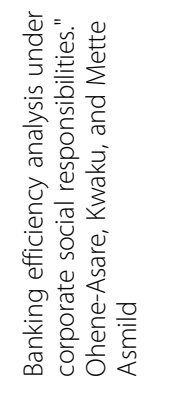 \\
\hline & $\stackrel{ \pm}{\sim}$ & $\stackrel{\sim}{\sim}$ & $\stackrel{\sim}{\sim}$ & $\approx$ \\
\hline
\end{tabular}


they argue shaped the CSR operations of the mining company that was researched in a case study. Their study which considered how the organisational practice of leadership and learning was applied to CSR implementation however did not indicate whether the success of implementing these practices of leadership and learning, had a relationship with the fact that the company is a multinational. Could an indigenous firm have successfully implemented leadership and learning to reinvent its CSR as was found in the case study by Dashwood and Puplampu, (2010)? Contextualising this study within the IB milieu could have provided an answer. This further buttresses the argument for CSR and IB research to be well situated within their peculiar environment.

Much as considered literature, largely agrees to the differences in CSR motives in developing and developed countries, Hinson and Ofori (2007) however argue that firms operating in Ghana also employ CSR as a public relations tool. This argument appears to be at variance with the impression created by Dartey-Baah and AmponsahTawiah (2011) that brand image is not relevant. Indeed, it will appear, judging from the communication of CSR activities by firms operating in Ghana, (both foreign and indigenous) that image does matter.

\section{Impression management theory}

A significant majority of included literature on CSR in Ghana applied stakeholder and institutionalism theories (Hinson et al., 2015; Nyuur et al., 2014; Amponsah-Tawiah, \& Dartey-Baah, 2012). However, we argue that firms in carrying out their CSR also seek to manage the impression that the public has of them. This therefore makes the Impression Management (IM) Theory, worth considering in studying CSR and IB in Ghana. Harris et al., (2007) defines Impression Management as "the process by which individuals try to influence the impressions others have of them" while Spear and Roper, (2013) describes it as "any action purposefully designed and carried out to influence an audience's perception of an organisation." With increasing public scrutiny on the operations of firms particularly multinationals, it stands to reason that they would, given the opportunity, use CSR to project a positive impression of themselves as asserted in the explanation of IM theory by Spear and Roper, (2013) and Harris et al. (2007).

According to Harris et al. (2007), initial studies on Impression Management concerned themselves with "the relationship between the frequency of specific tactic usage and work outcomes such as performance ratings and career success". Its origin is in psychology (Brennan et al. 2009), however the theory has subsequently been applied to different disciplines including management (Spear, \& Roper, 2013), thereby justifying the decision to apply it to the study of CSR and IB in Ghana. Another justification being that impression or reputation management gives second chances when crisis occur (Harris et al., 2007) just the same way that firms use their CSR activities to project a strong impression in times of crisis and crisis are not uncommon with IBs.

Multinational Corporations (MNCs) have over the years gained prominence as actors on the global scene and playing important role in not only driving foreign direct investment to developing countries, but also in the space of global governance (Barkemeyer, \& Figge, 2014). Their actions and inactions are under constant scrutiny with the advent of various global rating agencies, Non-Governmental Organisations (NGOs) and even their shareholders (Wilburn, \& Wilburn, 2013). The global campaign of Publish What You Pay, an advocacy for transparency in the extractive sector are notable civil society actions that have amplified the IB and global governance discourse (Publish What You Pay website). These developments compel IBs to often adopt the various IM behaviours to influence stakeholder perceptions. But probably the most important determinant of the impact of multinationals is the "way in which they operate and the roles and responsibilities they choose to assume" (Barkemeyer, \& Figge 2014) and these are likely to be influenced by the corporate values from the headquarters, the values of the home country, the values and laws of the host country as well as international standards. The preoccupation of MNCs therefore is not profitability alone but their "ability to meet the expectations of diverse constituents who contribute to its existence and success" (Gruber and Schlegelmilch, 2015), who also opine that multinationals will need to adapt their CSR programmes to suit the settings of the host country. Based on the above arguments, a study on CSR and IB in Ghana would be comprehensive if it also captures strategies firms adopt to look good in the face of varying and sometimes conflicting interests of stakeholders. This is supported by Gruber and Schlegelmilch (2015) who also argue that firms would have to balance their CSR programmes "between the conflicting priorities of global consistency and local responsiveness".

\section{Framework for CSR and IB research}

Kuada, and Hinson, (2012) have developed an integrated framework intended to aid investigations into CSR practices especially in developing countries. Their framework stems from previous disagreement by Wood (1991) that the seminal work by Carroll (1979) which captures CSR in four schematic responsibilities, was inadequate as a framework to examine CSR practices. Kuada and Hinson, (2012) therefore, picking from Jamali and Mirshak (2007), opine that a framework to guide investigations into CSR practices, must also point out what triggers CSR activities of firms. The scholars in their effort to develop a suitable framework, therefore synthesised the works of (Carroll 
1979) and Wood, (1991), and presented the CSR categories of Carroll as firms' motives for embarking on CSR activities. They then build on the "conventional antecedent-behaviour-consequence structure in the management literature", and argue that these motives will then determine which CSR issues will be important to the firm. They posit further that these CSR issues will in turn lead to the CSR outcomes. They subdivide the CSR outcomes into societal and corporate outcomes although they admit that the two could converge.

The appropriateness of this framework to our study is underlined by two major factors: 1 , that it was developed with the developing country context in mind; and 2, it was developed to help their investigation into CSR activities of IBs and also their local counterparts. Our paper, which examines CSR operations of IBs in Ghana therefore considers the framework, which is one of the few developed for the African context, as appropriate. However, we also recognise that the framework does not adequately provide for a holistic investigation of CSR activities of IBs, since we argue that CSR motives, key issues and outcome of IBs, do not exist in a vacuum but are influenced by various factors sometimes conflicting (Gruber \& Schlegelmilch, 2015). Our paper therefore proposes an extension of the framework of Kuada and Hinson (2012), to capture the unique exigencies of CSR practices of IBs, which are the conflicting priority of global consistency (international standards, values and interest of headquarters, home country) and local responsiveness (host country interest, values and laws) and how they impact CSR, as opined by Gruber and Schlegelmilch (2015).
For the purposes of the framework, we categorise these factors as; interests/values of firm's headquarters; interests/ values of home country; international standards and; interests/values of host countries, in no particular order. We make further contributions to the framework by suggesting that CSR outcomes are communicated, and communicated to create a positive impression about the company because inherently in CSR activities are public relations goals (Nyuur et al., 2014). We therefore employ the Impression Management theory to explicate how firms' CSR outcomes are communicated to create that positive impression.

The first quadrant contains CSR motives, the second, key CSR issues while the third are the outcomes for both society and the firm as explained by Kuada, and Hinson (2012). The societal outcomes as presented by Kuada and Hinson (2012) are Physical Environment, Social Welfare and Community Development among others. And the Corporate Outcomes include Earnings, Cost Reduction, Corporate Image and worker satisfaction among others. This paper however argues that in communicating these outcomes to stakeholders, firms attempt to influence a positive image of themselves by using IM behaviours, taking congnisance of the possible difference in cultural background of host and home country (Kim \& Bae, 2016). This paper also believes that all these stages of activity do not take place in a vacuum but are influenced by the values and interests of key constituents which are identified as the headquarters of the firm, home country of the firm, international CSR standards/rating agencies and finally the host country. A study of CSR and IB in Ghana would therefore be adequately addressed if it researched along the lines of the framework in Fig. 4 (IV).

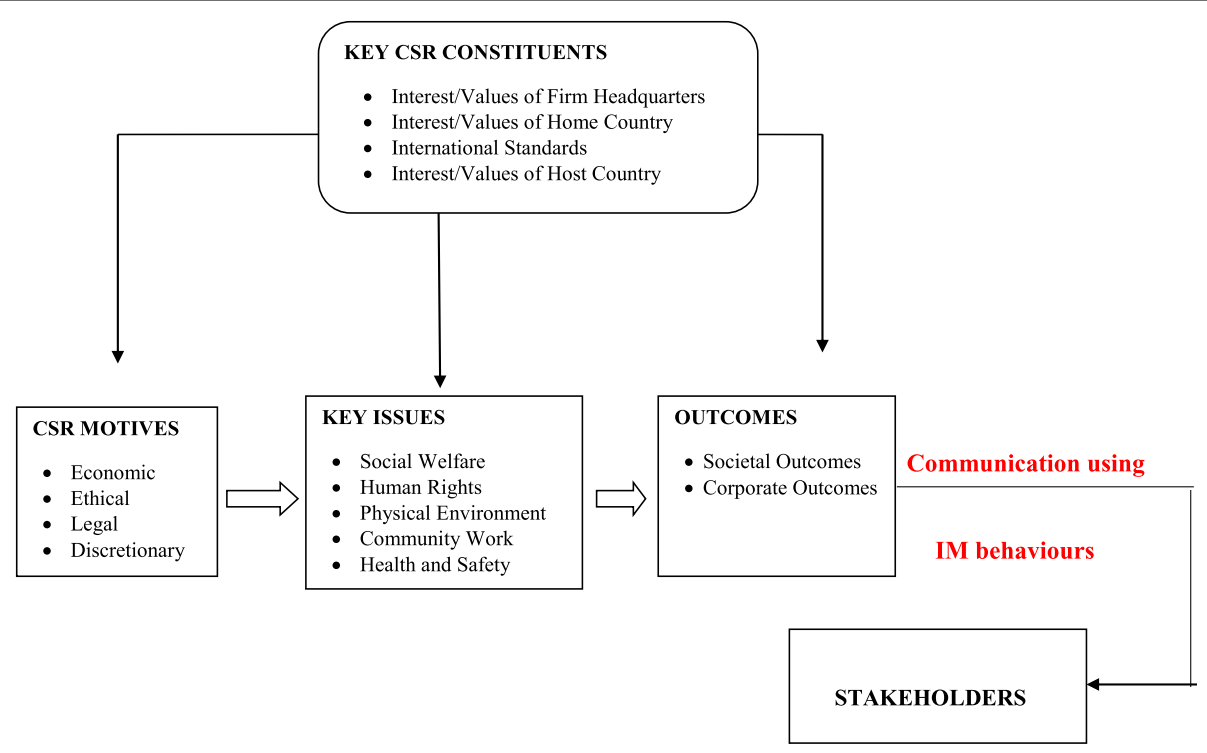

Fig. 4 CSR and IB in Ghana Framework 


\section{Conclusion}

It is evident from the review of literature that there is increased interest in CSR particularly after 2010, touching on various themes and subthemes in the rather amorphous concept. Predominantly, qualitative approach to research has been used although some studies also used quantitative methodology, with what appears to be a negligible use of mixed methods. However not much attention has been paid to CSR and IBs in Ghana in a more focused manner although some scholars in Ghana have looked at aspects of it. Stakeholder theory was identified to the dominant theory although a significant number of articles were not anchored on theories.

It is expected that CSR will continue to engage the attention of both practitioners and academics globally and more importantly in developing countries where poverty is pervasive and firms would be expected to complement government development agenda. The paper also asserts that the influence of the headquarters of IBs as well as their home and host countries will continue to impact the CSR operations of these firms and as societies become more informed and the world smaller due to technology, IBs would have a more daunting task navigating the sometimes conflicting priorities. Studies into CSR, particularly CSR and IB in developing or emerging economies could examine these nuances into details. The framework could also be tested by undertaking an empirical research.

\section{Abbreviations}

CSR: Corporate Social Responsibility; IB: International Business; IM: Impression Management; Mgt \& CSR: Management and Corporate Social Responsibility; MNC: Multinational Corporations; NGO: Non-Governmental Organisation

\section{Authors' contributions}

All four authors substantially contributed to article. All authors read and approved the final manuscript.

\section{Competing interests}

Authors hereby declare that there are no competing interests.

\section{Publisher's Note}

Springer Nature remains neutral with regard to jurisdictional claims in published maps and institutional affiliations.

\footnotetext{
Author details

${ }^{1}$ University of Ghana Business School, P.O. Box LG 78, Legon-Accra, Ghana. ${ }^{2}$ Department of Business and Management, Aalborg University, Fibigerstræde 4, Room: 103, 9220 Aalborg $\varnothing$, DK, Denmark. ${ }^{3}$ Institute of Statistical, Social and Economic Research, University of Ghana, P. O. Box LG 74, Legon-Accra, Ghana.
}

Received: 25 January 2017 Accepted: 22 May 2017

Published online: 12 June 2017

\section{References}

Abugre, J. B. (2014). Managerial role in organizational CSR: empirical lessons from Ghana. Corporate Governance, 14(1), 104-119.

Abugre, J. B., \& Nyuur, R. B. (2015). Organizations' commitment to and communication of CSR activities: insights from Ghana. Social Responsibility Journal, 11(1), 161-178.
Amponsah-Tawiah, K., \& Dartey-Baah, K. (2011), Corporate Social Responsibility in Ghana, International Journal of Business and Social Science, 2(17).

Amponsah-Tawiah, K., \& Dartey-Baah, K. (2012). CSR-OHS. Journal of Global Responsibility, 3(2), 224-234.

Amponsah-Tawiah, K., \& Mensah, J. (2015). Exploring the link between corporate social responsibility and health and safety in the mines. Journal of Global Responsibility, 6(1), 65-79.

Amponsah-Tawiah, K., Dartey-Baah, K., \& Osam, K. (2015). Turning potential collision into cooperation in Ghana's oil industry. Society and Business Review, 10(2), 118-131.

Barkemeyer, R., \& Figge, F. (2014). CSR in multiple environments: the impact of headquartering. Critical Perspectives on International Business, 10(3), 124-151.

Branco, C. M., \& Rodriques, L. L. (2007). Positioning stakeholder theory within the debate on corporate social responsibility. Electronic Journal of Business Ethics and Organization Studies, 12(1), 1-15

Brennan, N. M., Guillamon-Saorin, E., \& Pierce, A. (2009). Methodological Insights. Accounting, Auditing \& Accountability Journal, 22(5), 789-832.

Capaldi, N. (2016). New (other?) directions in corporate social responsibility. Journal of Corporate Social Responsibility, 1, 4. doi:10.1186/s40991-016-0005-5.

Carroll, A. B. (1979). A three-dimensional conceptual model of corporate performance. Academy of Managment Review, 4, 497-505.

Carroll, A. (1991). The pyramid of corporate social responsibility: towards the moral management of organizational stakeholders. Business Horizons, 34, 3948.

Cook, D. (1997). Systematic reviews: the case for rigorous methods and rigorous reporting. Canadian Journal of Anaesthesia, 44(4), 350-353.

Cooper, H. (2010). Research Synthesis and Meta-analysis: A Step-by-step Approach (4th ed.). Thousand Oaks: Sage Publications.

Dartey-Baah, K., \& Amponsah- Tawiah, K. (2011), Exploring the limits of Western Corporate Social Responsibility Theories in Africa, International Journal of Business and Social Science, 2 (18).

Dartey-Baah, K., Amponsah-Tawiah, K., \& Agbeibor, V. (2015). Corporate Social Responsibility in Ghana's National Development. Africa Today, 62(2), 70-93.

Dashwood, H. S., \& Puplampu, B. B. (2010). Corporate social responsibility and Canadian mining companies in the developing world: the role of organizational leadership and learning. Canadian Journal of Development Studies, 30(1-2), 175-196.

Dashwood, H. S., \& Puplampu, B. B. (2011). Organizational antecedents of a mining Firm's efforts to reinvent its CSR: the case of golden star resources in Ghana. Business and Society Review, 116(4), 467-507.

Denscombe, M. (2008). A Research Paradigm for the Mixed Methods Approach. Enterprise Journal of Mixed Methods Research, 2, 291-295.

Denyer, D., \& Tranfield, D. (2006). Using qualitative research synthesis to build an actionable knowledge base. Management Decision, 44(2), 213-27.

Eteokleous, P. P., Leonidou, L. C., \& Katsikeas, C. S. (2016). Corporate social responsibility in international marketing: review, assessment, and future research. International Marketing Review, 33(4), 580-624.

Franke, R. H., Edlund, T. W., \& Oster, F. (1990). The development of strategic management: journal quality and article impact. Strategic Management Journal, 11(3), 243-253.

Gruber, V., \& Schlegelmilch, B. B. (2015). MNEs' regional headquarters and their CSR agenda in the African context. International Marketing Review, 32(5), 576-602.

Harris, K. J., Kacmar, M. K., Zivnuska, S., \& Shaw, J. D. (2007). The impact of political skill on impression management effectiveness. Journal of Applied Psychology, 92(1), 278-285.

Hinson, R. (2011). Online CSR reportage of award-winning versus non awardwinning banks in Ghana. Journal of Information, Communication and Ethics in Society, 9(2), 102-115

Hinson, R., \& Kodua, P. (2012). Examining the marketing-corporate social responsibility nexus. International Journal of Law and Management, 54(5), 332-344.

Hinson, R. E., \& Ndhlovu, T. P. (2011). Conceptualising corporate social responsibility (CSR) and corporate social investment (CSI): the South African context. Social Responsibility Journal, 7(3), 332-346.

Hinson, R. E., \& Ofori, D. (2007). Corporate social responsibility (CSR) perspectives of leading firms in Ghana. Corporate Governance: The international journal of business in society, 7(2), 178-193.

Hinson, R., Boateng, R., \& Madichie, N. (2010). Corporate social responsibility activity reportage on bank websites in Ghana. International Journal of Bank Marketing, 28(7), 498-518.

Hinson, R. E., Gyabea, A., \& Ibrahim, M. (2015). Sustainability reporting among Ghanaian universities. Communication, 41(1), 22-42. 
http://www.gipcghana.com/invest-in-ghana/why-ghana.html. Accessed 13 May 2016.

http://www.publishwhatyoupay.org/about/objectives/. Accessed 22 May 2016.

Huang, H., \& Zhao, Z. (2016). The influence of political connection on corporate social responsibility___evidence from Listed private companies in China. International Journal of Corporate Social Responsibility., 1, 9. doi:10.1186/ s40991-016-0007-3.

INDUSTRY INFORMATION -TELECOM SUBSCRIPTION S FOR MARCH 2016 http:// www.nca.org.gh/downloads/Telecom_subscription_trends_for_March_2016. pdf. Accessed 13 May 2016.

Jamali, D., \& Mirshak, R. (2007). Corporate social responsibility (CSR): Theory and practice in a developing country context. Journal of Business Ethics, 72, 243262.

Kera"nen, J., Piirainen, K. A., \& Salminen, R. T. (2012). Systematic review on B2B branding: research issues and avenues for future research. Journal of Product \& Brand Management, 21(6), 404-417.

Kim, S., \& Bae, J. (2016). Cross-cultural differences in concrete andabstract corporate social responsibility (CSR) campaigns: perceived message clarityand perceived CSR as mediators. International Journal of Corporate Social Responsibility., 1, 6. doi:10.1186/s40991-016-0009-1.

Kolk, A. (2016). The social responsibility of international business: from ethics and the environment to CSR and sustainable development. Journal of World Business, 51(1), 23-34.

Kuada, J., \& Hinson, R. E. (2012). Corporate social responsibility (CSR) practices of foreign and local companies in Ghana. Thunderbird International Business Review, 54(4), 521-536.

Mahmoud, M. A., \& Hinson, R. E. (2012). Market orientation, innovation and corporate social responsibility practices in Ghana's telecommunication sector. Social Responsibility Journal, 8(3), 327-346.

Maignan, I., Ferrell, O. C., \& Ferrell, L. (2005). A Stakeholder Model for Implementing Social Responsibility in Marketing. European Journal ofMarketing, 39(9/10), 956-977.

Marano, V., \& Kostova, T. (2016). Unpacking the institutional complexity in adoption of CSR practices in multinational enterprises. Journal of Management Studies, 53(1), 28-54

Nyuur, R. B., Ofori, D. F., \& Debrah, Y. (2014). Corporate social responsibility in Sub-Saharan Africa: hindering and supporting factors. African Journal of Economic and Management Studies, 5(1), 93-113.

Ofori D. (2006), Business' corporate social responsibility: theory, opinion and evidence from Ghana. African Journal of Business and Economic Research 1.2 \& 3: pp. 11-40

Ofori, D. (2007a). Corporate social responsibility, myth, reality or empty rhetoric: perspectives from the Ghana stock exchange. The African Finance Journal, 9(2), 53-68.

Ofori, D. (2007), Social Responsibility and Ethics in Ghana: Stakeholders Expectations and Challenges in Okpara, J. (editor). Management and Economic Development in Sub-Saharan Africa: Theoretical and Applied Perspectives, pp. 63-97. Adonis \& Abbey Publishers.

Ofori, D. (2010a). Executive and management attitudes on social responsibility and ethics in Ghana: some initial exploratory insights. Global Partnership Management Journal, 1(1/2), 14.

Ofori, D. (2010b). Analysis of Corporate Sustainability \& Responsibility (The World Guide to CSR: A Country-by-Country Analysis). Ghana: University of Ghana Digital Collections.

Ofori, D. F., Nyuu, R. B., \& S-Darko, M. D. (2014). Corporate social responsibility and financial performance: Fact or fiction? A look at Ghanaian banks. Acta Commercii, 14(1), 1-11.

Poverty Reduction in Ghana: Progress and Challenges report Oct 2015 by the World Bankhttp://www.worldbank.org/en/country/ghana/publication/ poverty-reduction-ghana-progress-challenges. Accessed 13 May 2016.

Rosenstreich, D., \& Wooliscroft, B. (2012). Assessing international journal impact: the case of marketing. European Business Review, 24(1), 58-87.

Saha, S., Saint, S., \& Christakis, D. A. (2003). Impact factor: a valid measure of journal quality? Journal of the Medical Library Association, 91(1), 42.

Spear, S., \& Roper, S. (2013). Using corporate stories to build the corporate brand: an impression management perspective. Journal of Product \& Brand Management, 22(7), 491-501.

Tilt, C. A. (2016). Corporate social responsibility research: the importance of context. International Journal of Corporate Social Responsibility, 1, 2. doi:10. 1186/s40991-016-0003-7.
Tuokuu, X. F. D., \& Amponsah-Tawiah, K. (2016), Corporate social responsibility: Is it an alternative to government?, Journal of Global Responsibility, 7(1), 26-38. Visser, W. (2006), Revisiting Carroll s CSR Pyramid . In Crane and Matten (eds). Wilburn, K., \& Wilburn, R. (2013). Using Global Reporting Initiative indicators for CSR programs. Journal of Global Responsibility, 4(1), 62-75.

Wood, D. (1991). Corporate social performance revisited. Academy of Management Review, 16, 691-717.

\section{Submit your manuscript to a SpringerOpen ${ }^{\circ}$ journal and benefit from:}

- Convenient online submission

- Rigorous peer review

- Open access: articles freely available online

- High visibility within the field

- Retaining the copyright to your article

Submit your next manuscript at $\gg$ springeropen.com 